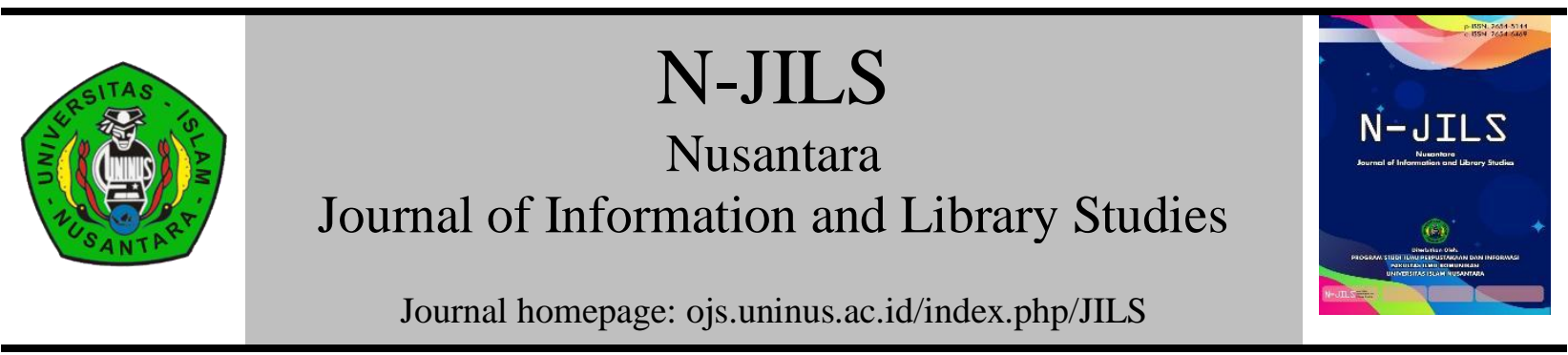

\title{
Penerapan Undang-Undang Keterbukaan Informasi Publik Di Dinas Perpustakaan Dan Kearsipan Kabupaten Luwu Timur
}

\section{Application of the Law on Public Information Disclosure at the Library and Archives Office of East Luwu Regency}

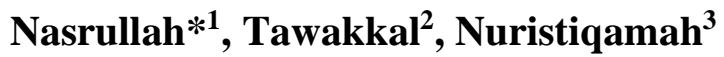 \\ 1,2,3 Universitas Islam Negeri Alauddin Makassar \\ Email: *1nasrullah.nasir@uin-alauddin.ac.id, ${ }^{2}$ tawakkal@uin-alauddin.ac.id, ${ }^{3}$ nuristy529@gmail.com
}

\begin{abstract}
ARTICLE INFO
Article history

Received [November, 2020]

Revised [December, 2020]

Accepted [December, 2020]

Available Online [December, 2020]

ABSTRACT

This study aims to determine the stages of the application of the Law on Public Information Openness and the obstacles faced by the Library and Archives Office of East Luwu Regency. This research uses descriptive research using a qualitative approach. This research was conducted at the Department of Library and Archives of East Luwu Regency. Methods of data collection through interviews, observation and documentation. The results showed the stages of implementing the Public Information Openness Law at the East Luwu Regency Library and Archives Service, namely through three stages. The three stages are analyzing information based on Law Number 14 of 2008 concerning public information disclosure; information is analyzed again based on the rules of the National Archives of the Republic of Indonesia (ANRI); and publish on the official website of the East Luwu Regency Library and Archives Service. As for the obstacles faced, namely the lack of competent human resources, and incomplete infrastructure.
\end{abstract}

Keywords: public information disclosure; dissemination of information; public library 
Kata kunci: keterbukaan

informasi publik; penyebaran

informasi; perpustakaan umum

\begin{abstract}
ABSTRAK
Penelitian ini bertujuan untuk mengetahui bagaimana tahapan penerapan Undang-Undang Keterbukaan Informasi Publik serta kendala yang dihadapi Dinas Perpustakaan dan Kearsipan Kabupaten Luwu Timur. Penelitian ini menggunakan penelitian deskriptif menggunakan pendekatan kualitatif. Penelitian ini dilakukan di Dinas Perpustakaan dan Kearsipan Kabupaten Luwu Timur. Metode pengumpulan data melalui wawancara, observasi dan dokumentasi. Hasil penelitian menunjukkan tahapan penerapan Undang-Undang Keterbukaan Informasi Publik pada Dinas Perpustakaan dan Kearsipan Kabupaten Luwu Timur, yaitu melalui tiga tahap. Ketiga tahap tersebut adalah menganalisis informasi berdasarkan UndangUndang Nomor 14 tahun 2008 tentang keterbukaan informasi publik; informasi dianalisis kembali berdasarkan aturan Arsip Nasional Republik Indonesia (ANRI); dan mempublikasikan pada website resmi Dinas Perpustakaan dan Kearsipan Kabupaten Luwu Timur. Adapun kendala yang dihadapi, yaitu kurangnya sumber daya manusia yang berkompeten, serta sarana prasarana yang kurang lengkap.
\end{abstract}

(C) 2020 NJILS. All rights reserved.

\section{A. PENDahuluan}

Dewasa ini perkembangan teknologi semakin maju dan pesat, begitu pula dengan perkembangan informasi yang sejalan dengan kemajuan teknologi saat ini. Informasi sudah menjadi bagian yang sangat penting dalam kehidupan masyarakat saat ini. Kebutuhan akan informasi dan komunikasi itu merupakan hal yang tidak kalah pentingnya dari kebutuhan sandang dan pangan manusia (Ahmad, 2012). Di era informasi saat ini, setiap orang berhak menggunakan akses dalam mendapatkan dan menyebarluaskan informasi. Apalagi negara kita yang menganut sistem demokrasi yang telah diatur oleh undang-undang.

Informasi yang tertutup atau sikap tidak transparan tentu akan berdampak buruk bagi pemerintahan, terutama dalam hal pelayanan publik dan juga akan berdampak rendahnya kualitas pengetahuan masyarakat. Pengaruh transparansi secara parsial sangat berpengaruh terhadap kualiatas pelayanan publik (Hermansyah et al. 2018). Jika informasi tertutup, maka pemerintahan dianggap otoriter atau pemerintahan yang berkuasa sendiri dan tidak demokratis. Hal ini menjadikan perlunya transparansi informasi, sehingga dapat tercipta keadilan yang menyeluruh bagi masyarakat.

Keterbukaan Informasi Publik (KIP) tentunya tidak lepas kaitannya dengan sistem demokrasi negara kita yang menjunjung tinggi kebebasan masyarakat berpendapat dan 
mendapatkan informasi. Undang-Undang No. 14 Tahun 2008 yang mengatur tentang Keterbukaan Informasi Publik (KIP) telah memenuhi salah satu hak asasi manusia serta memberikan harapan baru kepada setiap warga negara Indonesia dalam hal mendapatkan informasi. Undang-undang tersebut menjamin hak bagi setiap warga negara untuk memperoleh informasi (Nurdiansyah, 2016). Keberadaan Undang-Undang ini memberikan pencerahan dalam pelaksanaan penyelenggaraan negara atau pemerintahan. Pelaksanaan keterbukaan informasi publik dalam penyelenggaraan negara atau pemerintahan merupakan perwujudan tata pemerintahan yang baik (Good Governance), dan jaminan kepastian hukum terhadap hak masyarakat untuk mendapatkan informasi yang dibutuhkan, serta untuk turut serta dalam mengontrol penyelenggaraan negara atau pemerintahan. Pemerintah harus menyiapkan sarana prasarana; sumber daya manusia yang memiliki kemampuan (skill) dan kemauan. Selain itu juga diperlukan adanya komitmen dari seluruh penyelenggara pemerintahan atau badan publik dan aparat untuk melaksanakannya. Agar apa yang diharapkan dapat diwujudkan dengan baik.

Dalam mendukung pelaksanaan Undang-Undang No. 14 Tahun 2008 diperlukan adanya penegakan hukum yang berkeadilan, serta dukungan penegak hukum yang profesional dan yang menjunjung tinggi keadilan (Retnowati, 2012). Undang-undang ini sudah mulai diberlakukan di Indonesia pada tahun 2008. Sejak berlakuknya undang-undang ini pemerintah ditugaskan untuk mengelompokkan informasi mana yang wajib disampaikan atau diumumkan kepada masyarakat secara berulang-ulang dalam waktu tertentu, serta mengelompokkan informasi mana yang dikecualikan untuk disampaikan. Jadi, setiap pemerintahan ataupun pejabat harus bersedia terbuka dan menanamkan sifat kejujuran dalam memberikan informasi kepada masyarakat.

Penerapan Undang-Undang Keterbukaan Informasi Publik pernah diteliti oleh Febriananingsih (2012) yang meneliti tentang kesiapan lembaga-lembaga pemerintah dalam mengimplementasikan Undang-Undang Keterbukaan Informasi Publik dalam upaya mewujudkan tata pemerintahan yang baik. Pada penelitan ini ditemukan bahwa lembaga pemerintah belum siap mengimplementasikan Undang-Undang Keterbukaan Informasi Publik. Hal ini terlihat dari belum tersediannya informasi terkait dengan urusan tata pemerintahan, seperti kebijakan publik dan pelayanan publik. Penelitian ini lebih berfokus kepada kesiapan lembaga-lembaga pemerintah dalam mengimplementasikan Undang-Undang Keterbukaan Informasi Publik. Meskipun subjek penelitiannya sama membahas Undang-Undang Keterbukaan Informasi Publik, namun memiliki perbedaan dengan penelitian yang penulis lakukan. Pada 
penelitian sebelumnya lebih ke implementasi Undang-Undang Keterbukaan Informasi dalam mewujudkan tata kelola pemerintahan yang baik, sedangkan pada penelitian ini lebih berfokus kepada tahapan penerapan Undang-Undang Keterbukaan Informasi Publik, serta kendala dalam penerapannya di Dinas Perpustakaan dan Kearsipan Kabupaten Luwu Timur. Ketertarikan dalam meneliti Undang-Undang Keterbukaan Informasi Publik di Dinas Perpustakaan dan Kearsipan Kabupaten Luwu Timur karena Dinas Perpustakaan dan Kearsipan Kabupaten Luwu Timur ini merupakan lembaga yang mengelola, menyimpan dan menyebarluaskan informasi. Oleh karena itu, meneliti keterbukaan informasi publik pada lembaga pengelola informasi tentunya menarik untuk diketahui.

\section{B. TINJAUAN PUSTAKA}

Undang-Undang Nomor 14 tahun 2008 tentang keterbukaan informasi publik sering disebut sebagai Undang-Undang Keterbukaan Informasi Publik. Undang-undang ini merupakan undang-undang yang menyatakan bahwa informasi ialah kebutuhan pokok bagi setiap orang untuk pengembangan pribadi dan lingkungan sosialnya. Kebebasan dalam memperoleh informasi ini juga terdapat pada UUD 1945 pasal 28 F yang berbunyi, "Setiap orang berhak untuk berkomunikasi dan memperoleh informasi untuk mengembangkan pribadi dan lingkungan sosialnya, serta berhak untuk mencari, memiliki, menyimpan, mengolah dan menyampaikan informasi dengan menggunakan segala jenis saluran yang tersedia" (Komnasham, 2016). Berdasarkan isi UUD 1945 pasal 28 F ini menunjukkan bahwa hak memperoleh informasi merupakan hak asasi manusia. Selain itu, adanya keterbukaan informasi merupakan salah satu ciri penting negara demokratis yang menjunjung tinggi kedaulatan rakyat untuk mewujudkan penyelenggaraan negara yang baik.

Keberadaan Undang-Undang Nomor 14 tahun 2008 sangat penting, karena menjadi landasan hukum yang berkaitan dengan pemenuhan hak setiap warga negara untuk memperoleh berbagai informasi berkenaan dengan kegiatan penyelenggaraan negara, karena setiap badan publik seperti lembaga pemerintahan wajib menyediakan dan melayani permintaan informasi dari masyarakat yang mana jika informasi tersebut tidak termasuk dalam informasi publik yang dikecualikan, karena bersifat rahasia. Adapun pengertian Informasi publik adalah informasi yang dihasilkan, disimpan, dikelola, dikirim dan diterima oleh suatu badan publik yang berkaitan dengan penyelenggara dan penyelenggaraan Negara dan atau penyelenggara dan 
penyelenggaraan badan publik lainnya yang sesuai dengan undang-undang ini serta informasi lain yang berkaitan dengan kepentingan publik (Sastro, et.al, 2010).

Tujuan Undang-Undang Nomor 14 tahun 2008 ini, sebagaimana disebutkan dalam Pasal 2, yaitu: a) menjamin hak warga negara untuk mengetahui rencana pembuatan kebijakan publik, program kebijakan publik, dan proses pengambilan keputusan publik, serta alasan pengambilan suatu keputusan publik; b) mendorong partisipasi masyarakat dalam proses pengambilan kebijakan publik; meningkatkan peran aktif masyarakat dalam pengambilan kebijakan publik dan pengelolaan Badan Publik yang baik; c) mewujudkan penyelenggaraan negara yang baik, yaitu yang transparan, efektif dan efisien, akuntabel serta dapat dipertanggungjawabkan; d) mengetahui alasan kebijakan publik yang mempengaruhi hajat hidup orang banyak; e) mengembangkan ilmu pengetahuan dan mencerdaskan kehidupan bangsa; f) meningkatkan pengelolaan dan pelayanan informasi di lingkungan badan publik untuk menghasilkan layanan informasi yang berkualitas (Nurdiansyah, 2016).

Di dalam Undang-Undang Nomor 14 tahun 2008 ini diatur informasi yang wajib diumumkan secara berkala, yaitu: a) informasi yang berkaitan dengan Badan Publik; b) informasi mengenai kegiatan dan kinerja Badan Publik terkait; c) informasi mengenai laporan keuangan; d) informasi lain yang diatur dalam peraturan perundang-undangan. Adapun informasi yang wajib diumumkan secara merata adalah suatu informasi yang dapat mengancam hajat hidup orang banyak dan ketertiban umum. Kewajiban menyebarluaskan informasi publik ini disampaikan dengan cara yang mudah dijangkau oleh masyarakat dan dalam bahasa yang mudah dipahami. Selain informasi yang wajib diumumkan secara merata ada pula kategori informasi yang dikecualikan, seperti a) putusan badan peradilan; b) ketetapan, keputusan, peraturan, surat edaran, ataupun bentuk kebijaksanaan lain, baik yang tidak berlaku mengikat maupun mengikat ke dalam ataupun ke luar serta pertimbangan lembaga penegak hukum; c) surat perintah penghentian penyidikan atau penuntutan; d) rencana pengeluaran tahunan lembaga penegak hokum; e) laporan keuangan tahunan lembaga penegakkan hokum; f) Laporan hasil pengembalian uang hasil korupsi; g) informasi lain sebagaimana dimaksud dalam Pasal 11 ayat 2 (Republik Indonesia, 2008).

Dari hasil penelitian sebelumnya yang telah dilakukan oleh (Indah et.al., 2018) yang berjudul implementasi kebijakan keterbukaan informasi publik oleh di Dinas Kominfo pemerintahan Kota Tasikmalaya diketahui, bahwa faktor-faktor yang dapat mempengaruhi 
keberhasilan implementasi kebijakan, yaitu faktor komunikasi, sumber daya, disposisi dan struktur birokrasi sudah cukup terpenuhi dengan baik. Adapun kendala yang dihadapi biasanya berkaitan dengan faktor sumber daya, yaitu kurangnya jumlah staf seksi pelayanan informasi publik yang mempu menjadi implementor dalam kebijakan tersebut. Implementor yang baik harus memiliki keahlian, yaitu mampu mengoperasikan website dan juga media sosial sebagai sarana menyebarluaskan informasi publik. Selain itu, kendala lainnya adalah belum terpenuhinya fasilitas penunjang, seperti kamera profesional.

Penelitian lain yang juga dilakukan oleh Pambayun (2017) yang mebahas mengenai masalah implementasi kebijakan keterbukaan informasi publik pada Badan Perpustakaan dan Kearsipan Daerah Provinsi Jawa Barat. Hasil penelitian ini menunjukkan, bahwa, a) implementasi kebijakan keterbukaan informasi publik di Badan Perpustakaan dan Kearsipan Daerah Provinsi Jawa Barat belum berjalan efektif karena keterbatasan mempergunakan isi kebijakan dan konteks implementasi sehingga belum dapat terwujudnya keterbukaan informasi publik; b) untuk mendorong implementasi kebijakan keterbukaan informasi publik pada Badan Perpustakaan dan kearsipan Daerah Provinsi Jawa Barat agar lebih efektif dapat mengacu tahapan pelaksanaan kebijakan informasi publik yang digagas oleh Open Government Partnership.

Dua penelitian diatas lebih berfokus kepada kebijakan pemerintah daerah dalam implementasi kebijakaan Undang-Undang Keterbukaan Informasi Publik di dinas masingmasing. Efektifnya implementasi Undang-Undang Keterbukaan Informasi Publik bisa dilihat dari hasil penelitiannya, yaitu dengan adanya faktor pendukung dan kendala yang bisa diminimalisir. Pada penelitian ini meskipun objek penelitiannya juga pada dinas tapi penelitian ini lebih berfokus kepada tahapan penerapan yang dilakukan Dinas Perpustakaan dan kearsipan Kabupaten Luwu Timur. Oleh karena itu, penelitian ini lebih melihat segi teknis kesiapan dan tahapan penerapan Undang-Undang Keterbukaan Informasi Publik.

\section{METODE PENELITIAN}

Metode yang digunakan dalam menjawab permasalahan penelitian ini yakni penelitian deskriptif menggunakan pendekatan kualitatif. Metode kualitatif sering disebut metode naturalistik karena penelitiannya dilakukan pada kondisi alamiah (natural setting) dan data yang terkumpul serta analisisnya lebih bersifat kualitatif (Sugiyono, 2013). Adapun subjek penelitian 
ini dilakukan di lembaga Pemerintahan Kabupaten Luwu Timur, yaitu Dinas Perpustakaan dan Kearsipan Kabupaten Luwu Timur Provinsi Sulawesi Selatan. Penelitian ini dilaksanakan selama satu bulan mulai tanggal 29 Juni 2020 sampai 29 Juli 2020. Metode pengumpulan data yang peneliti lakukan ialah pengamatan (observasi), wawancara (interview), serta dokumentasi. Pengamatan atau observasi ialah salah satu teknik pengumpulan data dengan menggunakan pancaindera yaitu penglihatan, penciuman, pendengaran untuk mendapatkan sebuah informasi yang diperlukan (Mania, 2013). Wawancara, yaitu teknik pengumpulan data melalui proses tanya jawab lisan yang berlansung satu arah, artinya pertanyaan datang dari pihak yang mewawancarai dan jawaban diberikan oleh yang diwawancara (Fatoni, 2011). Wawancara dilakukan pada empat pustakawan yang bertugas dan bertanggung jawab atas penyabaran informasi di Dinas Perpustakaan dan Kearsipan Kabupaten Luwu Timur.

Tabel 1. Daftar Informan

\begin{tabular}{|c|l|l|c|}
\hline No & \multicolumn{1}{|c|}{ Nama Informan } & \multicolumn{1}{c|}{ Jabatan } & Informan \\
\hline 1 & Relince Miri, SE & Kepala Bidang Perpustakaan & Informan 1 \\
\hline 2 & Rasmawati, S.Sos & Kepala Bidang Kearsipan & Informan 2 \\
\hline 3 & Marlina, A.Md & Pustakawan Pelaksana & Informan 3 \\
\hline 4 & Tenri Hermanengsi, S.Pd.i & Arsiparis Pertama & Informan 4 \\
\hline
\end{tabular}

Sumber: Hasil Penelitian, 2020

Teknik pengolahan dan analisis data yang dilakukan yakni reduksi data, reduksi data merujuk pada proses pemilahan, pemokusan, penyerdehanaan, abstraksi, dan pentrasnformasian "data mentah" yang terjadi pada saat melakukan penelitian di lapangan (Emzir, 2016) . Peneliti kemudian memilih, merangkum hal-hal yang dianggap penting dan memfokuskan data yang telah di reduksi. Langkah selanjutnya ialah penyajian data (Display Data) Data yang telah direduksi kemudian peneliti melakukan penyajian data. Kemudian menarik kesimpulan dari data yang telah difokuskan ke hal-hal yang penting dan disusun secara sistematis ke dalam bentuk deskriptif. 


\section{HASIL DAN PEMBAHASAN}

Undang-Undang Nomor 14 tahun 2008 atau dikenal dengan Undang-Undang Keterbukaan Informasi Publik merupakan undang-undang yang disahkan oleh pemerintah di tahun 2008. Undang-undang ini mewajibkan lembaga pemerintah untuk menyebarluaskan informasi yang harus diumumkan kepada publik atau masyarakat sebagai bentuk transparansi dalam hal pemenuhan informasi kepada pemohon informasi. Selain informasi yang boleh disebarkan kepada masyarakat tentunya ada juga informasi yang tidak boleh disebarkan, seperti informasi yang dapat merugikan negara, rahasia negara atau bahkan informasi yang mengancam persatuan dan kesatuan negara Republik Indonesia.

Undang-Undang Keterbukaan Informasi Publik menjadi bagian penting dalam mengembangkan masyarakat yang sadar akan pentingnya keterbukaan informasi publik. Melalui undang-undang ini masyarakat dapat berpartisipasi dalam mengontrol setiap kebijakan pemerintah. Adanya kontrol masyarakat ini mendorong penyelenggaraan pemerintahan yang trasnparan dan akuntabel, sehingga membatasi terjadinya penyalahgunaan kewenangan dalam pemerintahan (Prabowo, 2013).

Keberadaan Undang-Undang Keterbukaan Informasi Publik di era saat ini sangat penting dimiliki setiap lembaga pemerintahan, apalagi banyaknya kasus-kasus korupsi yang terjadi di negara kita, maka dengan adanya Undang-Undang Keterbukaan Informasi Publik ini lembaga pemerintah diwajibkan untuk memberikan informasi kepada masyarakat melalui media penyebaran informasi, sehingga masyarakat bisa melihat transparansi lembaga pemerintah atau bahkan masyarakat juga bisa berpartisipasi dalam penyusunan kebijakan publik. Dengan kebijakan ini tentunya diharapkan terciptanya pelayanan yang baik dan tata kelola pemerintahan yang bersih.

Dinas Perpustakaan dan Kearsipan Kabupaten Luwu Timur merupakan salah satu lembaga pemerintahan di Kabupaten Luwu Timur Provinsi Sulawesi Selatan. Hal ini menjadikan adanya proses implementasi Undang-Undang Keterbukaan Informasi Publik sebagai program kerja di dinas tersebut.

Proses implementasi Undang-Undang Keterbukaan Informasi Publik di Dinas Perpustakaan dan Kearsipan Kabupaten Luwu Timur terlihat pada saat proses akan mempubikasikan atau menyebarkan informasi kepada masyarakat. Tahap pertama, informasi sebelum disebarkan dianalisis berdasarkan Undang-Undang Nomor 14 tahun 2008 tentang 
keterbukaan informasi publik. Tahap kedua, yaitu memilah informasi yang dapat disebarkan berdasarkan aturan Arsip Nasional Republik Indonesia (ANRI). Tahap satu dan dua ini menghasilkan informasi yang akan dikategorikan kedalam empat kategori, yaitu informasi yang wajib disediakan dan diumumkan secara berkala; informasi yang wajib disediakan dan diumumkan secara serta merta; kategori informasi yang wajib tersedia setiap saat; atau kategori informasi yang dikecualikan. Adapun informasi yang masuk dalam kategori informasi wajib disediakan dan diumumkan secara berkala, yaitu informasi tentang gambaran umum atau profil, visi misi, tugas pokok, fungsi, struktur organisasi, program, kegiatan, serta cara akses informasi di Dinas Perpustakaan dan Kearsipan Kabupaten Luwu Timur. Informasi yang termasuk dalam kategori informasi yang wajib tersedia setiap saat, yaitu informasi pada arsip statis, dokumendokumen peta, dan gambar-gambar. Adapun informasi yang kategori dikecuallikan adalah berbagai informasi yang bersifat rahasia dan dapat merugikan Dinas Perpustakaan dan Kearsipan Kabupaten Luwu Timur. Namun, tidak ada informasi yang termasuk dalam kategori informasi yang wajib disediakan dan diumumkan secara serta merta. Informasi yang tergolong pada kategori informasi wajib disediakan dan diumumkan secara berkala; dan kategori informasi yang wajib tersedia setiap saat ini kemudian memasuki tahap ketiga.

Tahapan ketiga, yakni meng-upload atau menyebarkan informasi yang telah dikumpulkan dan dipilih sebelumnya. Informasi tersebut disebarluaskan atau dipublikasikan melalui website resmi Dinas Perpustakaan dan Kearsipan Kabupaten Luwu Timur, yaitu pada link http://perpusarsip.luwutimurkab.go.id/. Pada website tersebut memuat berbagai data seperti berita, profil dinas, data bidang, PPID, saran dan pengaduan maupun kontak dari Dinas Perpustakaan dan Kearsipan Kabupaten Luwu Timur. 


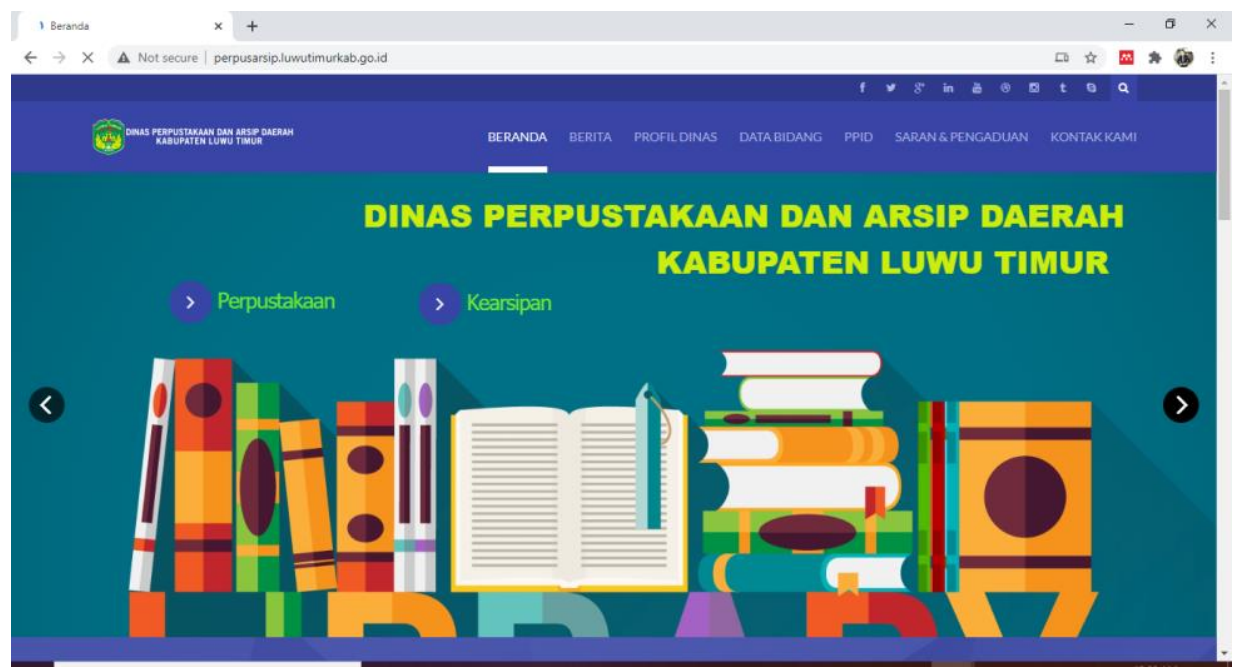

Gambar 1. Tampilan website Dinas Perpustakaan dan Kearsipan Kabupaten Luwu Timur Sumber: Hasil Penelitian, 2020

Adapun Kendala dalam implementasi Undang-Undang Keterbukaan Informasi Publik di Dinas Perpustakaan dan Kearsipan Kabupaten Luwu Timur, adalah, pertama, kurangnya sumber daya manusia yang berkompeten atau tenaga pengelola perpustakaan dan kearsipan yang mampu mengelolah atau menjalankan website dengan baik. Hal ini berkaitan dengan sumber daya manusia yang menguasai IT sangat kurang. Padahal, sumber daya manusia adalah seseorang yang memiliki kemampuan dalam melakukan aktivitas untuk mencapai suatu tujuan dalam sebuah organisasi. Keberhasilan sebuah organisasi akan ditentukan dari kerja keras yang kompeten dari orang-orang yang terlibat didalamnya. Oleh karena itu, pada Dinas Perpustakaan dan Kearsipan Kabupaten Luwu Timur, dibutuhkan sumber daya manusia yang memiliki kemampuan dibidang IT, sehingga proses publikasi informasi atau upload dokumen-dokumen di website tidak terhambat.

Kendala yang kedua, adalah sarana dan prasarana menjadi hal yang vital atau utama untuk terselenggaranya suatu roda organisasi belum memadai. Sarana merupakan segala peralatan yang dipakai secara langsung dalam mencapai maksud atau tujuan, alat dan media. Adapun prasarana adalah segala sesuatu yang merupakan penunjang utama terselenggaranya suatu proses (usaha, pembangunan, proyek dan sebagainya). Sarana dan prasarana di Dinas Perpustakaan dan Kearsipan Kabupaten Luwu Timur seperti komputer dan alat scanner untuk kebutuhan penyebarluasan informasi masih kurang. Selain itu, kualitas jaringan internet yang ada 
kurang stabil, sehingga mempengaruhi system operasi dan kualitas jaringan di website. Hal ini menjadikan website sering eror. Akibatnya proses penyebaran atau publikasi informasi dapat terhambat. Hal ini dikarenakan menurut Sari (2013), jaringan internet adalah sekelompok komputer dan perangkat terkait yang dihubungkan dengan fasilitas komunikasi dan menyebarkan informasi diseluruh penjuru dunia tanpa adanya batasan waktu, ruang, jarak, suku, bangsa, dan benua. Adanya berbagai kendala ini merupakan tantangan yang serius. Hal ini menurut Indah (2019), dikarenakan saat ini perpustakaan sebagai lembaga informasi harus mampu memaksimalkan semua potensi yang dimiliki termasuk koleksi sebagai sumber informasi dan sumber daya manusia yang ada, sehingga dapat memenuhi kebutuhan masyarakat saat ini.

\section{E. KESIMPULAN DAN SARAN}

Implementasi Undang-Undang Keterbukaan Informasi Publik di Dinas Perpustakaan dan Kearsipan Kabupaten Luwu Timur terlihat pada saat akan menyebarluaskan atau mempublikasikan informasi kepada masyarakat yang melalui tiga tahapan. Tahap pertama dan tahap kedua adalah proses analisis informasi yang tersedia berdasarkan Undang-Undang Nomor 14 tahun 2008 tentang keterbukaan informasi publik dan aturan Arsip Nasional Republik Indonesia (ANRI). Berdasarkan dua tahap ini menunjukkan bahwa informasi yang ada hanya tergoong kedalam tiga kategori informasi dari empat kategori informasi yang telah ditentukan. Ketiga kategori informasi tersebut adalah kemudian menghasilkan informasi kedalam dua kategori, yaitu informasi yang wajib disediakan dan diumumkan secara berkala; informasi yang wajib disediakan dan diumumkan secara serta merta; dan kategori informasi yang dikecualikan. Informasi yang tergolong pada kategori informasi wajib disediakan dan diumumkan secara berkala; dan kategori informasi yang wajib tersedia setiap saat ini kemudian memasuki tahap ketiga. Tahapan ketiga, yakni meng-upload atau menyebarkan informasi pada website resmi Dinas Perpustakaan dan Kearsipan Kabupaten Luwu Timur, yaitu pada link http://perpusarsip.luwutimurkab.go.id/. Adapun kendala yang dihadapi adalah berkaitan dengan sumber daya manusia yang masih kurang menguasai IT, serta sarana dan prasarana yang ada masih kurang. 
Saran yang dapat penulis sampaikan yakni diharapkan kepada pemerintah khususnya Kepala Dinas Perpustakaan dan Kearsipan Kabupaten Luwu Timur dan jajarannya betul-betul memberikan perhatian dalam penerapan Undang-Undang Keterbukaan Informasi Publik tersebut khususnya yang menjadi kendala seperti penyedian atau perekrutan tenaga ahli atau sumber daya manusia yang berkompeten dalam bidang teknologi serta penyediaan anggaran untuk kebutuhan sarana dan prasarana yang lebih lengkap, serta peningkatan kualitas jaringan internet yang baik untuk mempublikasikan dokumen-dokumen terkait informasi yang harus disampaikan ke masyarakat. Terkait tentang rancangan penelitian selanjutnya dapat meneliti tentang bagaimana peran pemerintah Kabupaten Luwu Timur dalam menyikapi kendala dalam penerapan UndangUndang Keterbukaan Informasi Publik khusunya di lembaga pemerintahan Kabupaten Luwu Timur.

\section{DAFTAR PUSTAKA}

Ahmad, A. (2012). Perkembangan Teknologi Komunikasi dan Kesenjangan Informasi: Akar Informasi dan Berbagai Standarnya. Jurnal Dakwah Tabligh, 13(1), 137-149. https://doi.org/https://doi.org/10.24252/jdt.v13i1.300

Dwi Prabowo, R. (2013). Implementasi Undang-Undang Keterbukaan Informasi Publik dalam Upaya Mewujudkan Good Governance ( Kajian Tiga Badan Publik: Bappeda, DPKAD dan Dinas Pendidikan Kota Semarang). Retrieved from https://media.neliti.com/media/publications/108143-ID-implementasi-undang-undangketerbukaan-i.pdf

Emzir. (2016). Metodologi penelitian kualitatif : analisis data. Jakarta: Rajawali Pers.

Fatoni, A. (2011). Metodologi Penelitian dan Teknik Penyusunan Skripsi. Jakarta: Rineka Cipta.

Hermansyah, I., Rahman, R., \& Suherman, M. (2018). Pengaruh Akuntabilitas dan Transparansi Terhadap Kualitas Pelayanan Publik (Survei Pada Dinas Daerah Kotatasikmalaya). Jurnal Akuntansi, 13(1), 20-28. Retrieved from http://jurnal.unsil.ac.id/index.php/jak/article/view/711

Indah, Rosiana Nurwa. (2019). Kontribusi Lembaga Informasi Di Era Disrupsi Dan Globalisasi. Nusantara Journal of Information and Library Studies (N-JILS), 2(1), 79-92. http://dx.doi.org/10.30999/n-jils.v2i2

Indah, T. (2018). Implementasi Kebijakan Keterbukaan Informasi Publik pada Dinas Kominfo Kota Tasikmalaya. Jurnal Komunikasi, 12(November 2017), 127-140. Retrieved from https://journal.uii.ac.id/jurnalkomunikasi/article/view/10967/8404

Komnasham. (2016). Hak untuk Tahu adalah Hak Asasi Manusia. Retrieved from Komnas HAM Republik Indonesia website: https://www.komnasham.go.id/index.php/news/2016/9/29/167/hak-untuk-tahu-adalah-hakasasi-manusia.html

Mania, S. (2013). Metodologi Penelitian Pendidikan dan Sosial. Makassar: Alauddin University Press.

Nunuk Febriananingsih. (2012). Keterbukaan Informasi Publik dalam Pemerintah Terbuka Menuju Tata Pemerintahan yang Baik. Jurnal Rechtsvinding, 1(10), 135-155. Retrieved from https://rechtsvinding.bphn.go.id/view/?id=149\&isi=artikel

Nurdiansyah, E. (2016). Mewujudkan Transparansi Bagi Masyarakat. Jurnal Bhinneka Tunggal Ika, 3(2), 147-151. Retrieved from https://ejournal.unsri.ac.id/index.php/jbti/article/view/4593/pdf 
Pambayun, K. G. (2017). Analisis implementasi kebijakan keterbukaan informasi publik pada badan perpustakaan dan kearsipan daerah provinsi jawa barat. Jurnal Politik Pemerintahan, 10(1), 97-108. Retrieved from http://ejournal.ipdn.ac.id/JPPDP/article/view/385

Republik Indonesia. (2008). Undang Undang Republik Indonesia Nomor 14 Tahun 2008 tentang Keterbukaan Informasi Publik. Indonesia: Sekretariat Negara.

Retnowati, E. (2012). Keterbukaan Informasi Publik dan Good Governance (Antara Das Sein dan Das Sollen). Jurnal Perspektif, 17(1), 54-61. https://doi.org/http://dx.doi.org/10.30742/perspektif.v17i1.94

Sari, L. H. (2013). Pengembangan Jaringan Local Area Network Menggunakan Sistem Operasi Linux Redhat 9 (Studi Kasus Pada Laboratorium Komputer SMA Negeri 1 Ujan Mas Kepahiang). Jurnal Media Infotama, 9(1), 165-189. Retrieved from https://jurnal.unived.ac.id/index.php/jmi/article/view/31

Sastro, D. A., Yasin, M., Gunawan, R., Julitasari, R., \& Bawor, T. (2010). Mengenal Keterbukaan Informasi Publik Mengenal Undang-Undang Keterbukaan Informasi Publik. Jakarta: Lembaga Bantuan Hukum Masyarakat.

Sugiyono. (2013). Metode Penelitian Pendidikan Pendekatan Kuantitatif, Kualitatif, dan R\&D. Bandung: Alfabeta. 